\title{
Territorial Accessibility and Decision-Making Structure Related to Debris Flow Impacts on Roads in the French Alps
}

\author{
Marina Utasse $^{1} \cdot$ Vincent Jomelli $^{1} \cdot$ Delphine Grancher $^{1} \cdot$ Frederic Leone $^{2}$. \\ Daniel Brunstein ${ }^{1} \cdot$ Clement Virmoux $^{1}$
}

Published online: 17 June 2016

(C) The Author(s) 2016. This article is published with open access at Springerlink.com

\begin{abstract}
The Alps are highly impacted by debris flows that cause major problems for companies and transport networks located in the valley bottoms. One such event occurred in the Rif Blanc catchment and affected the road network in the French Alps, as well as adjacent areas across the Italian border, for several days in June 2012. This article presents two independent approaches to vulnerability assessment. Based on investigations conducted during a survey of local authorities following the event, we compared theoretical risk management and real crisis management in terms of decision making and modes of intervention. Functional vulnerability and territorial consequences were analyzed using a best travel time model of accessibility. We show that a bottom-up approach is practiced in case of actual management planning with a central coordination of general council. Conversely theoretical crisis management shows prefect as the key actor supported by several other state institutions. Our analysis also revealed that a debris flow event with a local impact on the road network has territorial consequences at a regional scale. This study contributes to the discussion about how to minimize the vulnerability of alpine transport networks prone to debris flows. Our results could serve as a decision support tool for public authorities.
\end{abstract}

Vincent Jomelli

vincent.jomelli@1gp.cnrs.fr

1 UMR LGP: Laboratoire de Géographie Physique, Université Paris 1 Panthéon-Sorbonne/8591 CNRS, Meudon, France

2 UMR GRED: Gouvernance, Risque, Environnement, Développement, Université Montpellier/IRD, Montpellier, France
Keywords Crisis management - Debris flows · French Alps · Road network vulnerability

\section{Introduction}

Debris flows are rapid flows of saturated nonplastic debris within a steep channel (Hungr 2005) that owe their destructive power to the interaction of solid and fluid forces (Iverson 1997). In mountain areas like the Alps, debris flows are a serious threat as they periodically damage critical infrastructure and disrupt transport networks (Jomelli et al. 2011; Papathoma-Köhle et al. 2011; Fuchs et al. 2013). Because many valleys are landlocked, disruption of transport networks not only affects the damaged area, but extends to all areas and activities linked to it. Depending on the overall dependency of the region on the disrupted network, such situations can cause a considerable economic and social impact (Masiero and Maggi 2012).

In recent decades, many studies on the Alps were focused on understanding the dynamics of debris flows such as the meteorological conditions that were responsible for triggering slope failure (Caine 1980; Guzzetti et al. 2007) and links with climate change (Jomelli et al. 2007; Pavlova et al. 2014). But the likelihood that an exposed component would suffer damage as a result of a debris flow is a concept that has not been adequately explored and whose evaluation is not standardized (Gleyze 2007; Fuchs et al. 2007).

Originally, the concept of transport vulnerability was introduced by transport specialists to assess the consequences of a network disruption related to an accident, whatever its origin (Jenelius et al. 2006; Jenelius 2010). Road network vulnerability analysis can be defined as the study of potential degradation of the road transport system and its impact on society (Jenelius and Mattsson 2014), for 
example, economic impacts and delays. Most studies considered transport networks from the point of view of engineering: network connectivity/accessibility (Dalvi and Martin 1978; Chapelon 1996; Bell 2000; Berdica 2002; Sullivan et al. 2010), traffic flow, network reliability, and degradation of the road service (Wakabayashi and Kameda 1992; Gleyze and Reghezza 2007; Lhomme 2012; Tacnet et al. 2013).

Recent studies have focused on the direct impacts of debris flows on the road network in order to estimate the physical vulnerability of road infrastructure to gravitydriven hazards such as debris flows (Winter et al. 2014). Assessments of the structural and physical impacts of landslides and debris flows were proposed (Quan Luna et al. 2011; Papathoma-Khöle et al. 2012) that use fragility curves related to various infrastructures (Pitilakis et al. 2006). Other approaches consisted in identifying the parts of the roadway structure that are exposed to risk (Wieczorek et al. 2004; Galli and Guzzetti 2007; Geertsema et al. 2009; Winter et al. 2009, 2010). In the French Alps, Léone et al. (2011) combined assessing the physical vulnerability of the road network with modeling of both functional and territorial vulnerability to debris flows in terms of loss of accessibility in order to identify potentially vulnerable sections of the road. Beyond the issue of impacts Pramudita et al. (2014) raised the question of the quantity of debris left on a road. Budetta (2002) suggested calculating the "average vehicle risk" to measure the spatial probability of a vehicle being damaged in the debris flow hazard zone.

Despite these studies, two major issues are still poorly explored. The first concerns the indirect consequences of the disruption of a network for a territory due to a debris flow (Demoraes and D'Ercole 2009). The second issue is how decision-makers use the road network in the case of failure, especially in mountainous areas. In landlocked territories, the extent of damage to transportation and the speed of repairs are thus critical determinants of how quickly a disaster stricken area can recover (Chang 2003). Petrova (2006) suggested that the intensity of damage and its effects depend not only on the hazard itself, but also on protection and prevention measures. Atzl and Keller (2013) pointed out that critical network infrastructure is regulated by institutions in the social environment. Identifying these institutions and how they manage a crisis in the case of a network disruption is thus a major concern.

The present study had two goals. First, we wanted to evaluate the consequences of a debris flow event on the territorial accessibility in the French Alps including the Italian border. We wanted to estimate the real impact of the disruption on the whole road network. Our second goal was to analyze the decision-making process and emergency planning concerning the transportation network in the case of a debris flow whose intensity was moderate (with a recurrence interval of a few years) without fatalities that corresponds to the most debris flow cases in the French Alps (Pavlova et al. 2014). As a case study, we used a debris flow event that occurred on 4 June 2012, in the Rif Blanc catchment (French Alps) that impacted a road and disrupted the busiest link of the regional network for several days.

The article is organized as follows: in Sect. 2, we describe the study area and the damage to the road caused by the 4 June 2012 debris flow event. In Sect. 3, we present the two independent methods used to compare decision making and theoretical interventions by government authorities in the actual process that took place while the transport network was disrupted. In Sects. 4 and 5 we detail the differences between theoretical decision making concerning crisis management and that reported by the emergency services and actual loss of accessibility in the territory. Finally, in Sect. 6, we discuss the limits of our investigation.

\section{Study Area}

The field work was conducted in the French Alps. About five debris flow events are triggered each year by rainy events in this region and cause damage to the road network (Pavlova et al. 2014; Jomelli et al. 2015). Here we focus on a debris flow event that occurred on 4 June 2012 in the Hautes-Alpes district that was viewed as a representative case of debris flows in the French Alps that impact road network (Pavlova et al. 2014). This choice was based on several factors. The event was recent and post-event field investigations just after the event were possible. It impacted a strategic road that connects two departments and is used by a lot of vehicles each day. This portion of road has been already impacted by debris flows in the past decades. The volume of the debris flow event that occurred on 4 June 2012 was similar to previous events and not particularly important. The event did not cause injuries or fatalities and thus the risk management planning can be considered as representative of most debris flow cases in the French Alps.

\subsection{Debris Flow Event, 4 June 2012}

In the morning of 4 June 2012, a debris flow occurred in the Rif Blanc catchment following several rainy days in the Guisane valley, which is located in the northern part of the Hautes-Alpes region of the French Alps. The deposits extended 94 linear meters along the D1091 road and blocked it (Fig. 1). The physical damage was estimated by 
(a)
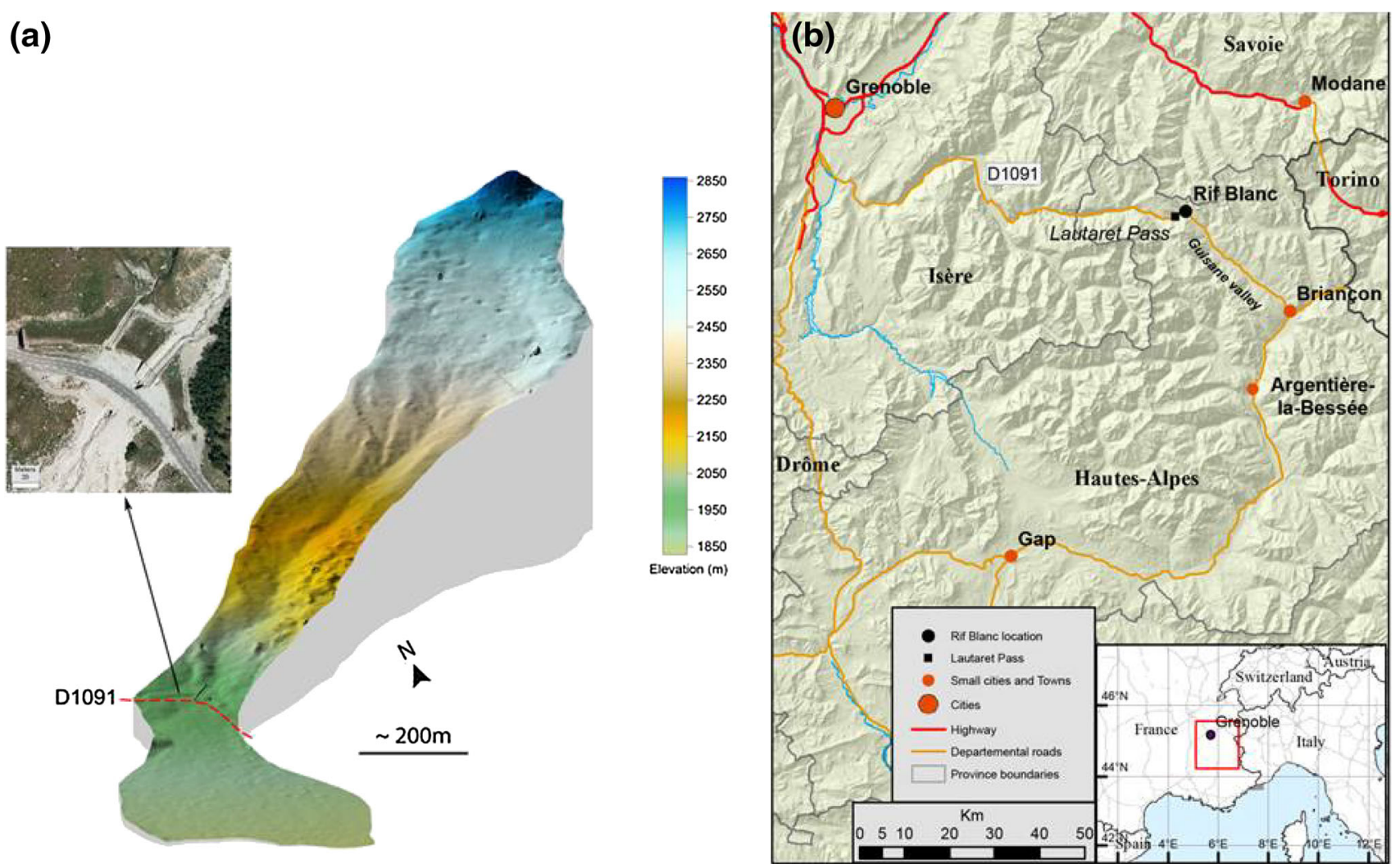

Fig. 1 Elevation representation of the Rif Blanc catchment with an aerial photograph of the D1091 road infrastructure in the catchment (a), and a shaded relief map of the main road network between the cities of Grenoble and Briançon (b)

the decision-makers to be about USD 30,000. Direct damage resulted in an $8 \mathrm{~h}$ blockage of road traffic despite the small volume of debris on the road, which was estimated between 10,000 and $15,000 \mathrm{~m}^{3}$ by the local authorities. The recurrence interval of an event of this scale is 1.8 per year.

Traffic was able to get through again in the late afternoon, but only on one lane, which necessitated a system of alternating traffic. The effects of the disturbance continued for a week with consequences not only for road traffic but also for the regional economy. During the disturbance, road users followed a detour route via the city of Gap to reach the Grenoble-Briançon axis.

This catchment is known to be active geomorphically, and at least five debris-flow events have been observed over the last 30 years. The first event in 2008 was recorded in the regional debris-flow survey, which has been conducted by the local authorities under the Department for the Restoration of Mountain Land (Service de Restauration des Terrains de Montagne; RTM) and the General Council of the Hautes-Alpes (Conseil Général des Hautes-Alpes) since the end of the nineteenth century. Most events occurred between May and July. Each event had an impact on a regional road that was then closed to road users with a comparable duration with the last event.

\subsection{Strategic Value of the D1091 Road}

The D1091 road that links Grenoble and Briançon is $117 \mathrm{~km}$ long, and is the only road that crosses the Guisane valley and the Lautaret pass (Fig. 1). The Guisane valley is close to Italy. The Lautaret pass is defined by the General Council of the Hautes-Alpes region (Tacnet et al. 2013) as the main economic link, and constant pressure is exerted by local decision-makers and tourism professionals to limit its closure. Indeed, the local population and professionals need continuous access to the valley. The densest road traffic is mainly in summer. In 2011, 2665 vehicles were counted per day per year, compared with 2757 vehicles per day in June, 4892 vehicles per day in July, and 4918 vehicles per day in August. Traffic in both directions passes through the entire section subject to debris flow hazard, but no protective measures have been taken so far. These facts highlight the vulnerability of this portion of the road network and its strategic value related to debris flow occurrence in the Rif Blanc catchment. 


\section{Conceptual Approach}

Initially we analyzed the decision-making processes before and after the debris flow crisis. We compared the theoretical diagnosis of crisis management provided by official state sources with real field measurements collected from interviews with decision-makers following the 4 June 2012 debris flow event that damaged the road network. Subsequently we focused on the loss of territorial accessibility due to the impacts of the debris flow on the road network. The accessibility of the road network was analyzed and allowed us to evaluate territorial vulnerability.

\section{Assessment of the Decision-Making Processes}

Our analysis of the decision-making processes was based on two separate steps. In the first step, we evaluated the theoretical risk management described by the authorities. In the second step, we conducted interviews with local decision-makers to estimate how risk management really proceeded during and after the debris flow event on 4 June.

\subsection{Evaluation of Theoretical Risk Management}

To better understand how the authorities reacted to events that impacted the road network, we conducted a crisis management analysis. We considered the intervention methods of different operational and organizational actors responsible for risk management with the aim to identify the specific role of the different actors and the hierarchy between actors. To this end we: (1) identified the most appropriate French administrative level for this kind of event; (2) determined the hierarchy between administrative institutions, civil protection, and management of the road networks; and (3) analyzed the actions and the decisionmaking processes implemented by managers, such as actions proposed by pre-crisis planning processes.

Our analysis focused on state decision-makers that are involved in crisis management at a regional and local scale related to the road network impacted by a natural hazard. Our goal was to identify who is doing what and who depends on whom. In order to construct an organization chart we visited national, regional, and local official websites of the different institutions involved in natural hazard crisis management (Sécurité civile dans la gestion des risques (defense and civil rescue service) ${ }^{1}$; Institut des Risques Majeurs (major risk institute) ${ }^{2}$; Direction

\footnotetext{
1 Sécurité civile dans la gestion des risques: http://www.interieur. gouv.fr/sections/a_1_interieur/defense_et_securite_civiles/gestion-risques.

${ }^{2}$ http://www.irma-grenoble.com/; http://www.cg05.fr/.
}

Régionale de l'Environnement, de l'Aménagement et du Logement (DREAL) de Provence Alpes Côte d'Azur (PACA); Cartographie des Risques Majeurs dans les Hautes- Alpes (regional department of natural hazard mapping) ${ }^{3}$; Services de l'Etat Relatif aux Risques Naturels dans les Hautes-Alpes (Hautes-Alpes natural hazards department $)^{4}$; Centre d'Information pour la Prévention des Risques Majeurs en Région PACA (Center of major risks prevention $)^{5}$; Direction Départementale des Territoires (DDT) des Hautes-Alpes (Direction of territories of the Hautes-Alpes department); Direction Interdépartementale des Routes (DIR) (interdepartmental direction of roads; Direction Régionale de l'Environnement (DIREN) (regional direction of environment), among others) because state management aims to prevent risks to the public. We also analyzed local services (for instance, the General Council of the Hautes-Alpes region, Regional Fire and Rescue Service, Police Center, Technical Regional Direction, National Forestry Authority) as we assumed that their local administrative level would be directly involved in crisis management.

We made several assumptions to adjust our diagnosis of risk management to reflect local conditions. Our crisis management hypothesis was based on:

(1) the vertical organization of the different authorities according to French levels of administration;

(2) such operations are the responsibility of local and regional services;

(3) mobilization of human and material resources is specific to interventions following natural hazard events, especially when debris flows affect the road network;

(4) local stakeholders in this mountain area are particularly dependent on the maintenance of the road network; and territorial isolation is a serious concern for local actors.

These assumptions helped us prepare interviews with local actors. The interviews would confirm (or not) our assumptions concerning crisis management.

\subsection{Interviews with Decision-Makers}

After the event, we analyzed the processes involved in the post-disaster decision-making and organizational processes by asking the authorities the questions listed in Table 1 .

Legal regulations, political organization, and the relationships between the different stakeholders can have a

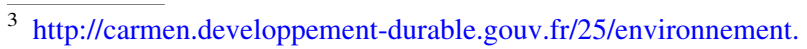
map.

${ }^{4}$ http://hautes-alpes.gouv.fr/risques-naturels-r128.html.

${ }^{5}$ http://90.80.175.228:8080/.
} 
Table 1 Questions asked during interviews

\begin{tabular}{|c|c|}
\hline Topic & Questions \\
\hline \multirow[t]{2}{*}{ Alert } & How were stakeholders informed of the event? \\
\hline & What warning systems were used? \\
\hline Decision process & What is your specific role in decision making / planning interventions during the crisis? \\
\hline \multirow[t]{2}{*}{ Intervention } & How long after the event did the intervention take place? \\
\hline & What resources were mobilized for traffic management and the removal of debris from the road? \\
\hline Communication & What information channels were available to the public and professionals about road conditions? \\
\hline Cooperation & $\begin{array}{l}\text { Are there any existing agreements or planned arrangements for traffic management between different regions and } \\
\text { neighboring countries? }\end{array}$ \\
\hline $\begin{array}{l}\text { Alternative } \\
\text { solution }\end{array}$ & What detour route is recommended when traffic between Grenoble and Briançon via the regional road D1091 is interrupted? \\
\hline
\end{tabular}

decisive impact on transport vulnerability. We divided the interviews into two parts: the first part concerned the local authorities responsible for the transport network and the second concerned independent actors who did not belong to the mentioned state institutions (Table 2). An analysis of local TV and press media gave us an idea of the response actions realized to cope with the debris flow event. Fortytwo local people were interviewed.

\subsection{Result of the Assessment of Decision-Making Structure}

Interviews with local decision-makers and other institution members made it possible to assess the theoretical decision-making structure and compare that structure with actual post crisis management.

\subsubsection{The Theoretical Decision-Making Process}

Despite the complexity of risk management procedures (and the lack of transparency in the decision-making process), we were able to define a theoretical decisionmaking process validated by the authorities. Figure 2 is an organizational chart of crisis management adjusted to a natural event of moderate intensity affecting the road network at a regional scale only, without fatalities.

The crisis management chart in Fig. 2 reflects the complexity of the procedures and the number of state institutions involved in the crisis management that follows a top-down management planning. The prefect is in charge of the management as soon as the impacts (direct or indirect as for the road network) of the natural hazard are larger than the territory of the village. Two levels of responsibility can be distinguished: at the higher level the prefect and the municipal administration make the decisions and plan the necessary actions, and at the lower level network managers, including the general council, are responsible for ensuring the maintenance of the road network.

This kind of crisis management is characteristically based on setting up temporary organizations devoted to help better communication between the different administrative institutions. These task forces temporarily bring

Table 2 Key actors interviewed

\begin{tabular}{|c|c|c|c|}
\hline Type & Institutions & $\begin{array}{l}\text { Administrative } \\
\text { level }\end{array}$ & Number of interviews \\
\hline \multirow{7}{*}{$\begin{array}{l}\text { Institutional } \\
\text { actors }\end{array}$} & Prefect & \multirow[t]{5}{*}{ Regional } & One person from the administration staff \\
\hline & $\begin{array}{l}\text { General Council of Hautes- } \\
\text { Alpes }\end{array}$ & & Four people from road and risk services \\
\hline & Technical Regional Direction & & One person (the project manager of Natural Hazards) \\
\hline & National Forestry Authority & & Seven people from RTM (service managers, engineers, technicians) \\
\hline & $\begin{array}{l}\text { Regional Fire and Rescue } \\
\text { Service }\end{array}$ & & Six people (service managers and fire brigades from different towns) \\
\hline & Police Center & \multirow[t]{2}{*}{ Local } & Six people (service managers and local stations) \\
\hline & Town Hall & & $\begin{array}{l}\text { Eight people from technical services of Monetier, Briancon, and Argentiere } \\
\text { town halls }\end{array}$ \\
\hline \multirow{3}{*}{$\begin{array}{l}\text { Independent } \\
\text { actors }\end{array}$} & Staff of archives & \multirow[t]{3}{*}{ Regional } & Two people \\
\hline & Members of associations & & Four people (video associations, local geological association) \\
\hline & Staff of media & & Three people from Dauphiné Libéré journal \\
\hline
\end{tabular}




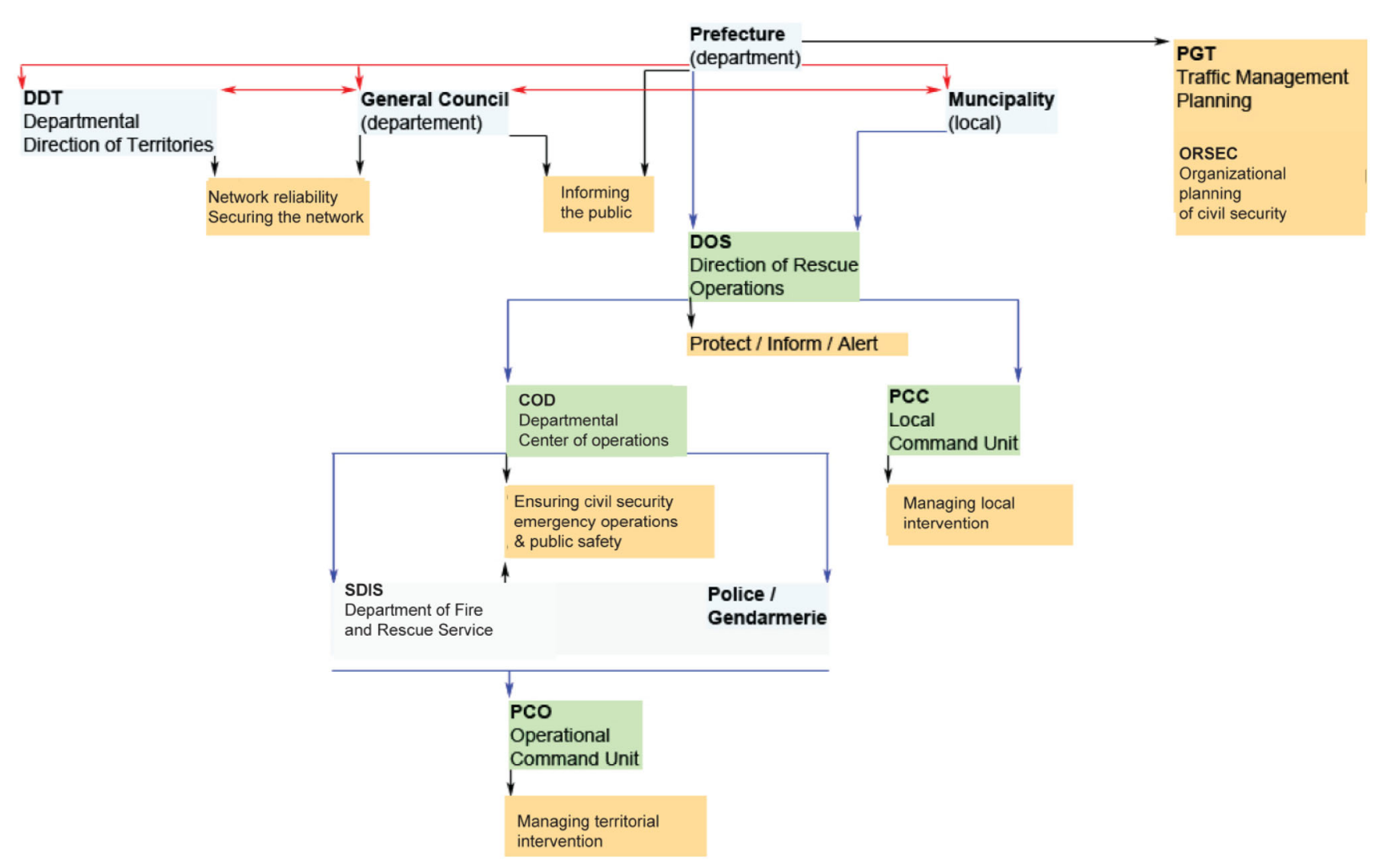

-Decision-Makers

- Task Force

-Action

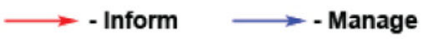

Fig. 2 Theoretical decision-making organizational chart that would apply to territorial authorities in the case of a natural hazard affecting the regional road network

together the representative decision-makers of each service. They are supervised by the prefect and the mayor. The chart provides information on the hierarchy of authorities, but no details are given on the time required to plan actions or organize executive missions.

\subsubsection{Actual Management of the Crisis Following the Event Based on Information Collected in Interviews with Decision-Makers}

Interviews with decision-makers immediately after the event allowed us to compare what actually happened with the information provided by government sources. This approach addresses the issue of responsibility of decisionmakers, their modes of intervention, their reactivity in the face of a damaging event, and their modes of communication (Fig. 3).

The first warning usually comes from an eye witness (a road user, for example) calling from a cell phone or from an emergency call box (Step 1, Fig. 3). Road patrols may also raise the alarm. In both cases, the call is relayed to the public emergency services (Step 2, Fig. 3). These services relay the information directly to the network managers involved. In parallel, the military police are in charge of regulating traffic and ensuring road safety. The time lag between the alert and the intervention should be less than $1 \mathrm{~h}$.

Figure 3 reveals the differences between the theoretical organization summarized in Fig. 2 and what really happened. The actual organization is based on a bottom-up process that does not strictly follow the same links and hierarchies between state institutions as those reported in Fig. 2. Here we noticed that the decision-makers differ from those involved in the theoretical crisis management. The General Council of the Hautes-Alpes department is the chief network manager in the operational chain (Step 3, Fig. 3) together with its territorial agencies. No government services at all are listed as leader in Fig. 3 and the role of the municipality is smaller than indicated in the theoretical organization chart (Fig. 2). The Prefect's staff is informed by Gendarmerie. The General Council is involved in each step of crisis management, maintenance 


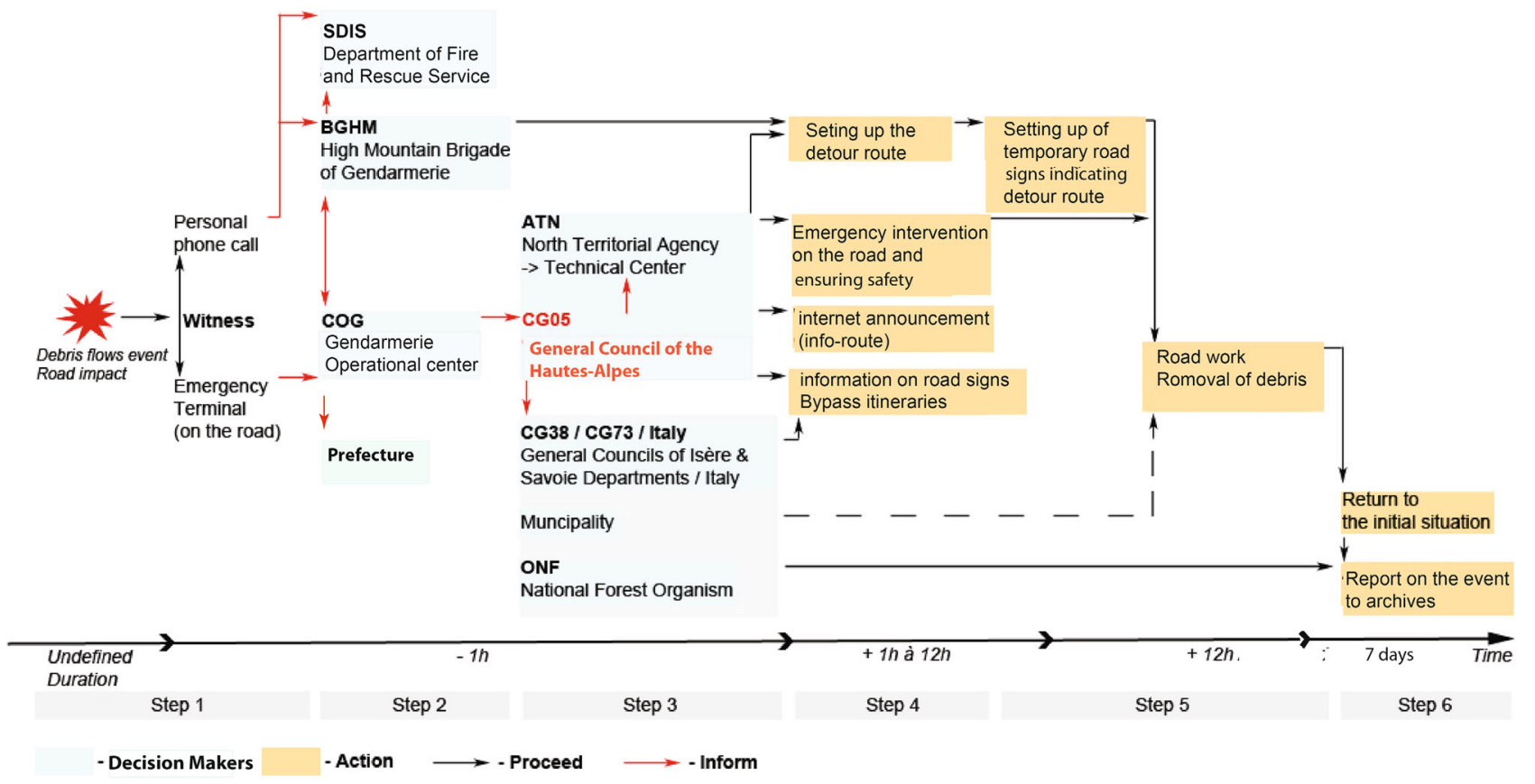

Fig. 3 The actual decision-making process and management of the crisis after a debris flow event affected the regional road network

of the road network, any necessary interventions, and the governance of the territory. It is in charge to inform people of bypass solutions. This differs from the theoretical administrative hierarchy of state services depicted in Fig. 2.

The human and material resources deployed on site (Step 4, Fig. 3), as well as the information for road users, are not specific to a debris flow event. The procedure is the same for any kind of damage to the road network. According to the network managers, a landlocked territory caused by a blocked road network does not appear to be a cause of real fear. In the case of an occasional event, the crisis could be resolved in a relatively short time (Step 5, Fig. 3) and a detour route set up until the situation returns to normal. Contrary to the information provided by official government websites, there is no particular action plan for a natural hazard that affects the transport network.

The General Councils provide a live broadcast of traffic conditions via a specific internet platform, along with information for road users, on electronic road signs. This information is intended to warn road users. In the case of the Rif Blanc debris flow event, the information was displayed on signs between the cities of Grenoble and Briançon.

Network managers told us in their interviews that they consider operational coordination and communication to be indispensable (Step 3, Fig. 3). For that reason, possible cooperation is currently under discussion between France and Italy for the management of the network at international scale. Existing communication channels between General Council and its counterparts in neighboring regions allow traffic detours to be set up and the public to be informed (Step 4, Fig. 3). Yet no official procedure exists for cooperation with other state authorities responsible for the management of the French transport network. Despite efforts to increase trade and to develop partnerships, joint management of the transport network at the scale of the French Alps is still difficult, especially organization, communication, and action planning. This type of communication currently depends on sporadic informal exchanges between (governmental) agents. Conflicts of interest at the level of managers may prevent the establishment of real collaborative projects.

Decision-makers only focused on the direct impacts of debris flow and on the regional organization of road traffic on the day the event took place. But Steps 5 and 6 in Fig. 3 show that debris were removed from the road about $12 \mathrm{~h}$ after the event and it was seven days before the road traffic returned to normal. The interviews suggest that all decision-makers underestimated the functional consequences of the event, such as how long the disturbance would last, the extent of the network affected, and the difficulties encountered in ensuring the best possible continuity of transport despite the disruption of the network. The main concern of official decision-makers was restoration of a section of road traffic as quickly as possible to avoid anyone being isolated. 
Table 3 Travel speed classes as a function of the degree of importance of the road

\begin{tabular}{|c|c|c|c|}
\hline $\begin{array}{l}\text { Administrative classes of roads } \\
\text { (BDTOPO) }\end{array}$ & Attribute value (BDTOPO) & $\begin{array}{l}\text { Averaged speed } \\
\left(\mathrm{km} \mathrm{h}^{-1}\right)\end{array}$ & Travel speed class \\
\hline Main road & $\begin{array}{l}\text { Links major cities } \\
\text { Links countries } \\
\text { Highways, express national roads }\end{array}$ & 110 & 1 \\
\hline Main road & $\begin{array}{l}\text { Links regions } \\
\text { Links high-priority traffic between major cities } \\
\text { Provides an alternative to highways with tolls } \\
\text { Allows traffic to bypass cities }\end{array}$ & 70 & 2 \\
\hline Secondary road & $\begin{array}{l}\text { Connects cities } \\
\text { Connects regions } \\
\text { Serves localities and major tourist areas } \\
\text { Crosses obstacles (bridges, mountain passes, etc.). }\end{array}$ & 60 & 3 \\
\hline Secondary road & $\begin{array}{l}\text { Provides local links in rural areas } \\
\text { Structures traffic in urban areas }\end{array}$ & 50 & 4 \\
\hline
\end{tabular}

\section{Loss of Territorial Accessibility Assessment}

Our analysis was conducted in two steps. In the first step, we evaluated network disruption, and in the second step, we used a model to quantify territorial vulnerability.

\subsection{Evaluation of Network Disruption: Territorial Accessibility Indicators}

We used simple accessibility indicators as input variables to assess travel possibilities. This is standard procedure before more complex accessibility models are used (Morris et al. 1979). In the present case, the indicators were travel time, distance, and cost including fuel and road tolls of the different alternative routes. Accessibility indicators were used to evaluate the ease of connecting to the transport system in the case of a change in the spatial organization of the network. This approach involves defining the exact start location and the exact destination of the journey.

\subsection{Network Modeling}

We used an accessibility model to quantify the loss of territorial accessibility in terms of difference in travel time using the damaged network. For the present study, we used the RouteFinder model based on Dijkstra's algorithm (1959) to estimate accessibility from a starting point in a network to an endpoint. The network is represented by a graph, symbolized by arcs for road segments and nodes denoting intersections. RouteFinder operates directly in a GIS environment with attribute data and was configured only for light vehicles. A calculation of difference in travel time between normal and road damage situations (due to longer travel distance only) is made automatically with RouteFinder.

The road database used in this study was the BD TOPO provided by the IGN (Institut géographique national / National Geographic Institute). RouteFinder requires a table of network features (Table 3). This table has to consider both the relative hierarchy of each axis and a user's travel direction (Appert and Chapelon 2006). These two parameters are important because they affect the level of accessibility. Since the model is based on the travel time concept, the main factor to be considered is the speed limit on each type of axis. This parameter was averaged using web-based route planning calculators. This avoids overestimating the results by using the maximum speed limit, which does not necessarily reflect real travel time.

\subsection{Definition of the Scenarios}

The Grenoble-Briançon itinerary was chosen as the reference road axis (Fig. 1). This itinerary corresponds to a regional road connecting two strategic urban nodes in the alpine region. Next, we identified all possible detour routes that could be used in the case of traffic disruption in the Guisane valley. All these routes were taken into account in the model, including the borderland area with Italy.

Two types of scenarios were compared to assess territorial accessibility: (1) a normal situation with no disruption of the road network; and (2) the situation in the aftermath of the Rif Blanc debris flow event. The route from Grenoble to Briançon was chosen for both scenarios.

Given the scale of the network in the study area, territorial accessibility in terms of travel time was broken down into discrete classes of $30 \mathrm{~min}$ as a compromise between 
the accuracy of the results and the computation time required. The best travel time is the minimum accessibility value between the two places and reflects the optimal functioning of the transport network in a given time interval (Chapelon 2003).

\subsection{Results of the Loss of Territorial Accessibility}

The loss of territorial accessibility was analyzed considering distance, time, and cost, which are detailed below.

\subsubsection{Detour Routes, Distance, Time, and Cost}

In the case of traffic disruption on the D1091 road linking Grenoble and Briançon, the General Council of the HautesAlpes suggests one main detour to road users. To get a better view of territorial accessibility, we compared all alternative roads in the Alpine transport network (Fig. 4):

- Itinerary 1 (IT1) (Reference route). Main itinerary: Grenoble-Briançon using the RD1091 road in the normal situation, via the Guisane valley.

- Itinerary 2 (IT2). Grenoble-Briançon by way of Gap and Argentière-la-Bessée on roads RN85, RN94, as suggested by the General Council of Hautes-Alpes Department to road users.

- Itinerary 3 (IT3). Grenoble-Briançon by way of Isère Department, Gap, and Argentière-la-Bessée, highway A51, departmental roads D1075 and D994, national road RN94.

- Itinerary 4 (IT4). Grenoble-Briançon by way of Modane in Savoie Department and Italy: highway A41, highway A43, national road RN94.

The shortest detour was itinerary 2, but the fastest travel time was on itinerary 4 using limited access (autoroute) highways. The disruption of the network added one hour or more travel time to all itineraries. Road users had to drive at least 72 additional kilometers to reach the same destination. The cost reached as much as three times the original cost.

\subsubsection{Mapping Territorial Loss of Accessibility}

Modeling road accessibility based on GIS enabled us to compute a map of accessibility. This map shows the extra time needed for access at the regional scale in a disturbed situation due to a network disruption in the Rif Blanc catchment. The map was based on the previously established detour routes between the cities of Grenoble and Briançon, including Italy. The entire road network was included to better represent the consequences of the disturbances at the regional scale.
The map of additional access time shows a gradual deterioration of accessibility in the disturbed situation along with the scenario showing the normal situation from the city of Grenoble to Briançon (Fig. 5). The whole of the northern part of the Hautes-Alpes Department is affected by a delay time longer than one hour in accordance with Figs. 4 and 5 (portion of road in red on Fig. 5). Road disturbances affect both main and secondary roads. However, the disruption did not create a situation of isolation even if access to the valley corridors was very disturbed, especially in the tourist valleys to the north of the towns of Briançon and Gap. The linear representation of the degradation of territorial accessibility shows the impact on the two main detour roads via the towns of Gap and Argentière-la-Bessée.

Figure 5 shows the access time from Grenoble city to the whole territory. Normally, the road section in orange in Fig. 5 should be reached by using the Rif Blanc road. The normal duration of the travel is $125 \mathrm{~min}$ (Fig. 4, IT1). Due to the failure at Rif Blanc, however, an extra travel time is needed from Grenoble because drivers have to use a longer, more southerly route via Gap that passes through Argentière-la-Bessée (IT2 in Fig. 4).

\section{Discussion and Conclusion}

Most studies of vulnerability on road networks prone to natural hazards focus on structural impacts (Jomelli 2011). In this article, we attempted to document the structure of crisis management made for this kind of event that affects a road network in mountain areas of France. This study tackles the concept of indirect risk by assessing the territorial consequences of the disruption of a road network caused by a debris flow. Here we focused on a crisis management devoted to a natural hazard with moderate intensity. However, new investigations are needed to explore the possible differences in actual crisis management applied in case of an intense (low return period) debris flow event with fatalities or a debris flow event that impacts a road that connects France to Italy.

Comparison of the theoretical risk management model (based on information provided by government sources) with the actual situation after the debris flow event (as reported by local decision-makers in interviews) allowed us to identify the actors involved in crisis management in terms of decision making, liability, and interventions. The comparison revealed that, in practice, crisis management is the responsibility of regional network managers rather than of the government authorities usually featured in organizational charts depicting French risk management. Overall, the physical impacts on the road and the functional disturbances were satisfactorily managed by the government 

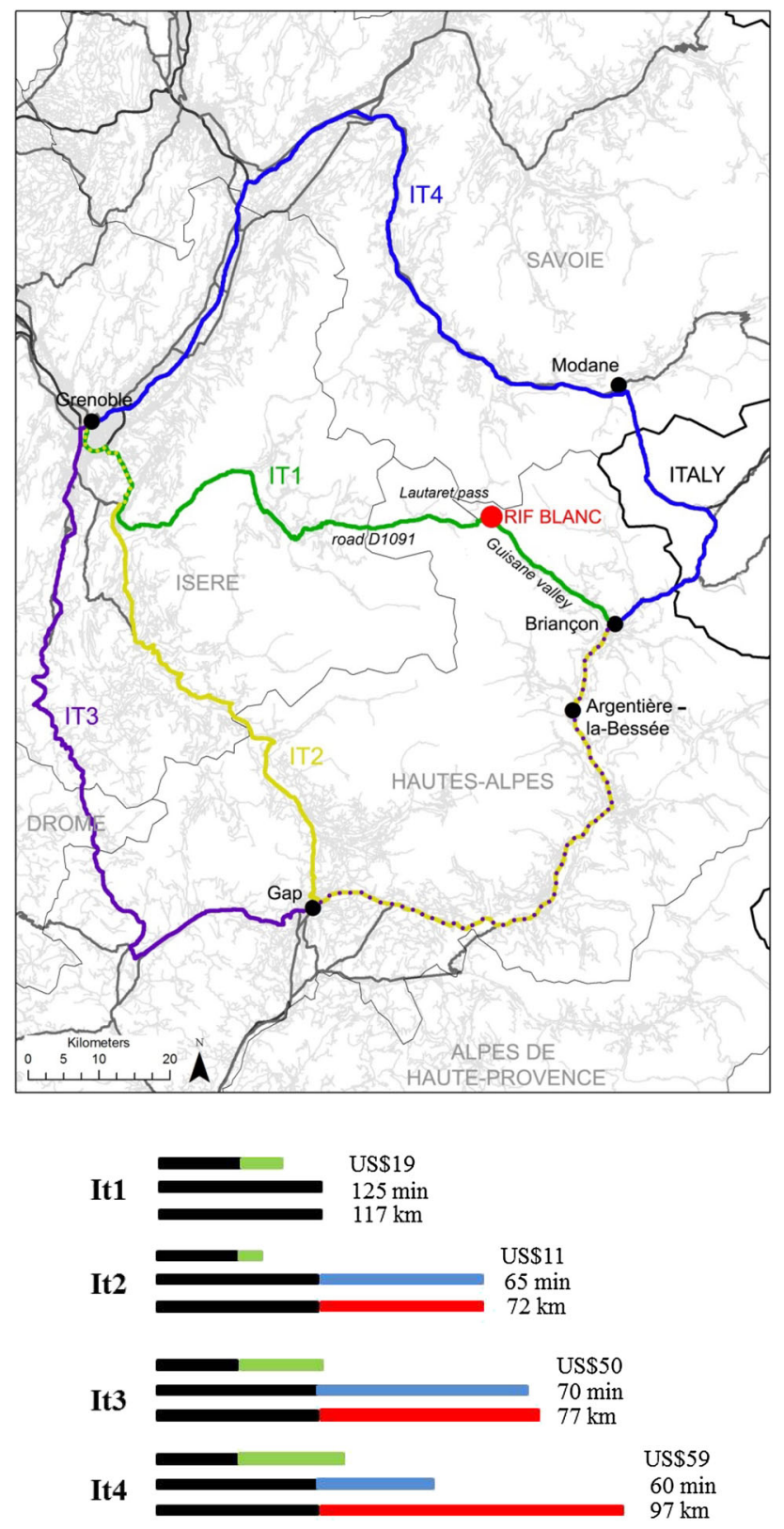

Fig. 4 Possible routes from Grenoble to Briançon in kilometers (km), access time in minutes (min), and cost in USD (fuel, road tolls). In the bar chart, the reference itinerary 1 is in black; green shows the extra cost; blue shows the extra time, and red the extra kilometers compared with itinerary 1

officials. Our analysis shows that a debris flow event with a local impact on the road network has territorial consequences at the regional scale. Efforts were made to propose rapidly a bypass to the impacted road section at Rif Blanc catchment area. But several days were needed to return to the initial situation, involving extra travel time and cost for several hundred of people. It is however interesting to recall that several debris flows occurred in the past in the same catchment with about the same impacts on road.

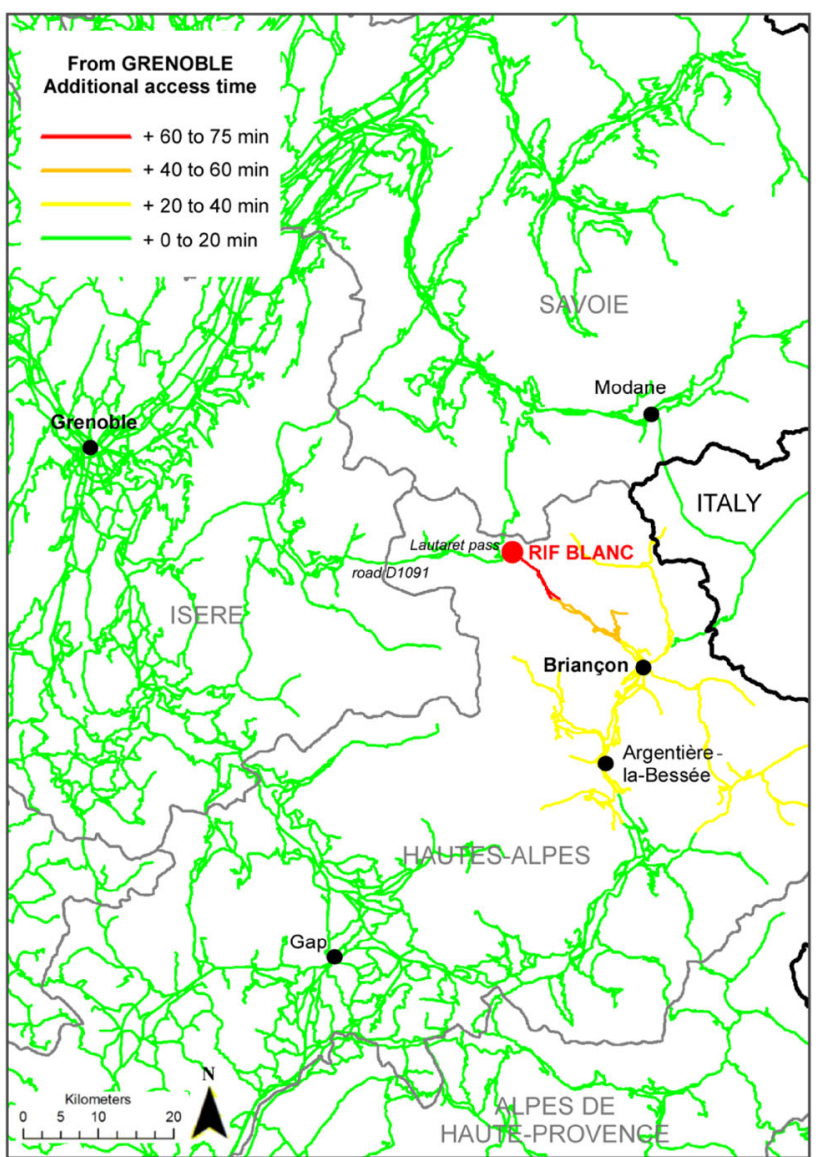

Fig. 5 Difference in access time (in minutes) from Grenoble between normal and disturbed situations caused by a debris flow event in the Rif Blanc catchment (total road cut). This additional access time is calculated using the fastest road to each section of the territory. The major impact is obtained for the Briançon area

Despite these frequent events the adaptation and resilience strategies in the management planning are still limited as we could expect a shorter time to recover the initial situation.

Theoretical management planning envisages temporary organizations devoted to help better communication between the different administrative institutions. The actual crisis management did not use such temporary organization that is probably difficult to set up rapidly. Despite the fact that this portion of road is close to the Italian border, the communication with Italy was limited to electronic road signs in France only.

Our field surveys were only conducted with institutional network managers. To complete our analysis, it would be useful to compare these results with surveys of network users including transport companies or local inhabitants who regularly use these roads. A quantification of the real socioeconomic impacts of such consequences based on an accurate description of people (number, profession, 
destination, and so on) would help to determine the global cost of such seven-day delay.

Our model of road accessibility did not include the flow of traffic or the ability of detour roads to cope with the volume of road flow (Jenelius et al. 2006). The use of accessibility graphs could be combined with multi-agent models to assess the impact of road disturbances by simulating the shift in the flow of road traffic (Sahal and Morin 2012).

Acknowledgments The work described in this article was supported by the project Eranet Circle-Mountain Arnica "Assessment of Risks on transportation Networks resulting from slope Instability and Climate change in the Alps." This support is gratefully acknowledged. We would like to express special thanks to the Restauration des Terrains de Montagne in the district of Hautes-Alpes for allowing us to use their database. The authors also gratefully acknowledge the reviewers for their helpful comments and their effort to improve and clarify this manuscript.

Open Access This article is distributed under the terms of the Creative Commons Attribution 4.0 International License (http://crea tivecommons.org/licenses/by/4.0/), which permits unrestricted use, distribution, and reproduction in any medium, provided you give appropriate credit to the original author(s) and the source, provide a link to the Creative Commons license, and indicate if changes were made.

\section{References}

Appert, M., and L. Chapelon. 2006. The vulnerability of urban road networks related to degradation (La vulnérabilité des réseaux routiers urbains face aux risques d'altération) Géorisques 3(2): 47-58 (in French).

Atzl, A., and S. Keller. 2013. A systemic approach for the analysis of infrastructure-specific social vulnerability. In From social vulnerability to resilience: Measuring progress toward disaster risk reduction, ed. S. Cutter, and C. Corendea, 27-43. UNUSOURCE 17/2013. Bonn: The United Nations University Institute for Environment and Human Security (UNU-EHS).

Bell, M.G.H. 2000. A game theory approach to measuring the performance reliability of transport networks. Transportation Research Part B 34(4): 533-545.

Berdica, K. 2002. An introduction to road vulnerability: What has been done, is done and should be done. Transport Policy 9(1): 117-127.

Budetta, P. 2002. Risk assessment from debris flows in pyroclastic deposits. Bulletin of Engineering Geology and the Environment 61(4): 293-301.

Caine, N. 1980. The rainfall intensity-duration control of shallow landslides and debris flows. Geography Annals Series A 62(1): 23-27.

Chang, S.E. 2003. Transportation planning for disasters: An accessibility approach. Environment and Planning A 35(1): 1051-1072.

Chapelon, L. 1996. Multiscale modeling of transport networks: Towards higher accurate accessibility (Modélisation multiéchelles des réseaux de transport: vers une plus grande précision de l'accessibilité). Mappemonde 3: 1051-1072 (in French).

Chapelon, L. 2003. Evaluation of intermodal transport chains: The aggregation of measurements in space and time (Évaluation des chaînes intermodales de transport: l'agrégation des mesures dans l'espace et le temps). In Proceedings of the International Conference Technological Innovation for Land Transportation (TILT), Lille 2-4 December 2003, 167-178 (in French).

Dalvi, M.Q., and K.M. Martin. 1978. The measurement of accessibility: Some preliminary results. Transportation 5(1): 17-42.

Demoraes, F., and R. D'Ercole. 2009. Risks and accessibility of places in Quito district (Ecuador) (Risques et accessibilité des lieux dans le district Métropolitain de Quito (Equateur)). Mappemonde 95(1): 1-20 (in French).

Dijkstra, E.W. 1959. A note on two problems in connexion with graphs. Numerische Mathematik 1(2): 269-271.

Fuchs, S., K. Heiss, and J. Hübl. 2007. Towards an empirical vulnerability function for use in debris flow risk assessment. Natural Hazards and Earth System Sciences 7(5): 495-506.

Fuchs, S., M. Keiler, S. Sokratov, and A. Shnyparkov. 2013. Spatiotemporal dynamics: The need for an innovative approach in mountain hazard risk management. Natural Hazards 68(3): $1217-1241$.

Galli, M., and F. Guzzetti. 2007. Landslide vulnerability criteria: A case study from Umbria, Central Italy. Environnement Management 40(4): 649-665.

Geertsema, M., J.W. Schwab, A. Blais-Stevens, and A. Sakals. 2009. Landslides impacting linear infrastructure in west central British Columbia. Natural Hazards 48(1): 59-72.

Gleyze, J.F. 2007. Making allowances for spatial and network effects when assessing indicators on infrastructure network nodes. Cybergeo 370(1): 22-46.

Gleyze, J., and M. Reghezza. 2007. Structural vulnerability as a tool for understanding the mechanisms of damage ( $L a$ vulnérabilité structurelle comme outil de compréhension des mécanismes d'endommagement). Géocarrefour 82(1): 17-26 (in French).

Guzzetti, F., S. Peruccacci, M. Rossi, and C.P. Stark. 2007. Rainfall thresholds for the initiation of landslides in central and southern Europe. Meteorology Atmospheric Physics 98(2): 239-267.

Hungr, O. 2005. Classification and terminology. In Debris flow hazards and related phenomena, ed. M. Jakob, and O. Hungr, 10-23. Berlin: Springer.

Iverson, R.M. 1997. The physics of debris flows. Reviews of Geophysics 35(3): 245-296.

Jenelius, E. 2010. Redundancy importance: Links as rerouting alternatives during road network disruptions. Procedia Engineering 3(1): 129-137.

Jenelius, E., and L.G. Mattsson. 2014. Road network vulnerability analysis: Conceptualization, implementation and application. Computers, Environment and Urban Systems 49: 136-147.

Jenelius, E., T. Petersen, and L.G. Mattsson. 2006. Importance and exposure in road network vulnerability analysis. Transportation Research Part A 40(3): 537-560.

Jomelli, V., D. Brunstein, D. Grancher, and P. Pech. 2007. Is the response of hill slope debris flows to recent climate change univocal? A case study in the Massif des Ecrins (French Alps). Climate Change 85(1): 119-137.

Jomelli, V., I. Pavlova, M. Utasse, M. Chenet, D. Grancher, D. Brunstein, and F. Leone. 2011. Are debris floods and debris avalanches responding univocally to recent climatic change: A case study in the French Alps. In Climatic change: Geophysical foundations and ecological effects, ed. J. Blanco, and $\mathrm{H}$. Kheradmand, 423-444. Rijeka, Croatia: InTech.

Jomelli, V., I. Pavlova, N. Eckert, D. Grancher, and D. Brunstein. 2015. A new hierarchical Bayesian approach to analyse environmental and climatic influences on debris flow occurrence. Geomorphology 250(1): 407-421.

Léone, F., J. Deymier, L. Chapelon, A. Colas, and V. Jomelli. 2011. Debris flows and road accessibility in the French Alps: Characterization and modeling of physical, functional and 
territorial vulnerabilities (Debris flows et accessibilité routière dans les Alpes françaises: caractérisation et modélisation des vulnérabilités physiques, fonctionnelles et territoriales). In Actes du XXIVème Colloque de l'Association Internationale de Climatologie, Rovereto, Italie, September 2011, 369-374 (in French).

Lhomme, S. 2012. Structural analysis of technical networks: Modeling, properties, vulnerabilities (L'analyse structurelle des réseaux techniques: modélisations, propriétés, vulnérabilités). https://halshs.archives-ouvertes.fr/halshs-00664023. Accessed 12 Dec 2014 (in French).

Masiero, L., and R. Maggi. 2012. Estimation of indirect cost and evaluation of protective measures for infrastructure vulnerability: A case study on the transalpine transport corridor. Transport Policy 20(1): 13-21.

Morris, J., P.L. Dumble, and M.R. Wigan. 1979. Accessibility indicators for transport planning. Transportation Research A 13(1): 91-109.

Papathoma-Köhle, M., M. Kappes, M. Keiler, and T. Glade. 2011. Physical vulnerability assessment for alpine hazards: State of the art and future needs. Natural Hazards 58(3): 645-680.

Papathoma-Khöle, M., M. Keiler, R. Totschnig, and T. Glade. 2012. Improvement of vulnerability curves using data from extreme events: Debris flow event in South Tyrol. Natural Hazards 64(3): 2083-2105.

Pavlova, I., V. Jomelli, D. Brunstein, D. Grancher, E. Martin, and M. Déqué. 2014. Debris flow activity related to recent climate conditions in the French Alps: A regional investigation. Geomorphology 219(2): 248-259.

Petrova, E. 2006. Vulnerability of Russian regions to natural risk: Experience of quantitative assessment. Natural Hazards and Earth System Sciences 6(1): 49-54.

Pitilakis, K., M. Alexoudi, S. Argyroudis, O. Monge, and C. Martin. 2006. Earthquake risk assessment of lifelines. Bulletin of Earthquake Engineering 4(3): 365-390.

Pramudita, A., E. Taniguchia, and A.G. Qureshia. 2014. Location and routing problems of debris collection operation after disasters with realistic case study. Procedia - Social and Behavioral Sciences 125(3): 445-458.

Quan Luna, B., J. Blahut, C.J. van Westen, S. Sterlacchini, T.W.J van Ach, and S.O. Akbas. 2011. The application of numerical debris flow modeling for the generation of physical vulnerability curves. Natural Hazards and Earth System Sciences 11(3): 2047-2060.

Sahal, A., and J. Morin. 2012. Effects of the October 25, 2010, Mentawai tsunami in La Réunion Island (France): Observations and crisis management. Natural Hazards 62(1): 1125-1136.

Sullivan, J.L., D.C. Novak, L. Aultman-Hall, and D.M. Scott. 2010. Identifying critical road segments and measuring system-wide robustness in transportation networks with isolating links: A link-based capacity-reduction approach. Transportation Research Part A 44(2): 323-336.

Tacnet, J.M., E. Mermet, E. Zadonina, M. Deschatres, P. Humbert, J.C. Dissart, and S. Labbe. 2013. Road network management in the context of natural hazards: A decision-aiding process based on multi-criteria decision making methods and network structural properties analysis. Proceedings of the International Snow Science Workshop, Grenoble, 912-919.

Wakabayashi, H., and H. Kameda. 1992. Network performance of highway systems under earthquake effects: A case study of the 1989 Loma Prieta earthquake. Proceedings of the US-Japan Workshop on Earthquake Disaster Prevention for Lifeline Systems. Tsukuba Science City, Japan, 215-232.

Wieczorek, G.F., G.S. Mossa, and B.A. Morgan. 2004. Regional debris-flow distribution and preliminary risk assessment from severe storm events in the Appalachian Blue Ridge Province, USA. Landslides 1(1): 53-59.

Winter, M.G., F. Macgregor, and L. Shackman (eds.). 2009. Scottish road network landslides study: Implementation. Edinburgh: Transport Scotland.

Winter, M.G., J. Dent, F. Macgregor, P. Dempsey, A. Motion, and L. Shackman. 2010. Debris flow, rainfall and climate change in Scotland. Quarterly Journal of Engineering Geology and Hydrogeology 43(4): 429-446.

Winter, M.G., J.T Smith, S. Fotopoulou, K. Pitilakis, O. Mavrouli, J. Corominas, and S. Argyroudis. 2014. An expert judgement approach to determining the physical vulnerability of roads to debris flow. Bulletin of Engineering Geology and the Environment 73(2): 291-305. 